Flores, M. A. \& Ferreira, F. I. (2018) Education and child poverty in times of austerity in Portugal: implications for teachers and teacher education, in O. McNamara \& J. McNicholl (eds). Poverty Discourses in Teacher Education, Milton Park: Routledge, 2018, ISBN: 978-0-81538524-0

\title{
Education and Child Poverty in Times of Austerity in Portugal: Implications for Teachers and Teacher Education
}

\author{
Maria Assunção Flores \\ Fernando Ilídio Ferreira \\ University of Minho, Portugal
}

\begin{abstract}
This paper draws upon data drawn from ongoing research on the effects of poverty on teaching and teacher education. It looks at student teachers' experiences during practicum in regard to issues of poverty at school as well as the ways in which it is framed and discussed during their initial teacher preparation. In total 19 female student teachers participated. They were enrolled at a Master's Degree in Pre-school and in both Preschool and Primary school. Data were collected through written narratives. Key findings point to student teachers' perceptions about poverty and its impact on children's wellbeing and equal opportunities; the strategies they employed to deal with poverty at school and the complex role of the teacher in promoting equity and social justice through facilitating and acting as a facilitator of access to powerful knowledge for all children. Implications for teacher education are discussed, particularly the need to foster its social and cultural dimension.
\end{abstract}

\section{Introduction}

Over the last few years Portugal has also gone through a severe financial and economic crisis with implications for all sectors of society. Austerity measures have been intensified since the implementation of the Memorandum of Understanding with the International Monetary Fund, the European Central Bank and the European Commission (the Troika). They have greatly affected people's lives, in terms of unemployment, low income, high taxation, poverty, inequalities as well as issues of social protection, health, 
and education, amongst other vital aspects. Thus, alongside the financial and economic downturn, a social crisis has also become apparent in various ways.

In the Education sector, salary cuts, high rate of unemployment, high taxation and worsening of teacher career progression are but a few examples of the ways in which the teaching profession has been affected. Recent research has demonstrated the intensification, the increase in bureaucracy, and low morale of the teaching workforce (Flores 2014). The goal of this paper is twofold: i) to do a brief characterisation of the emerging picture of a context of crisis as well as the austerity measures that have affected schools and teachers' work and education; and to look at preliminary findings from ongoing research on the effects of poverty on teaching and teacher education. Particularly, it focuses on student teachers' experiences during practicum in regard to issues of poverty at school as well as the ways in which it is framed and discussed during their initial preparation. Before presenting the study, a brief overview of the wider context is presented, particularly in regard to the education sector and initial teacher education in Portugal.

\section{Economic crisis, austerity measures and child poverty in Portugal}

Portugal was one of the 12 countries most affected by the world recession (UNICEF 2014), visible in the deterioration of the situation of families, mostly related to job losses, underemployment, higher taxes, cuts in social transfers and public services which occurred between 2008 and 2012. The intervention of the Troika in 2011 led to the worsening of living conditions and to an increase of poverty. Along with this was the growing emigration of Portuguese qualified young people, due to the lack of employment. Data from Eurostat, issued in June 2015, indicate that Portugal presented the fifth higher rate in the European Union in terms of unemployment of youngsters and that the rate has increased: $7.6 \%$ in 2008 and $13.2 \%$ in 2015. Portugal, with around 10.5 million of inhabitants, is nowadays one of the main emigration countries in the world. Long-term emigration increased with the recession, particularly since 2010. According to a recent report (Pires, Pereira, Azevedo \& Ribeiro 2014), on average, around 80,000 people have left Portugal between 2007 and 2012 per year. In 2013, the number increased to 110,000 people, including a huge number of young qualified people.

In 2012, roughly a quarter of Portugal's population were "at risk" of poverty or social exclusion, according to Eurostat data (EU 2013). Amongst other tough policies, in 
2011, for example, the Portuguese government cut public sector wages, increased taxes and slashed spending on social welfare programmes that provided social security benefits. Austerity measures were adopted as part of a larger goal to reduce the deficit below $5.9 \%$. Although successful in reducing the deficit, the austerity measures severely harmed the status of Portuguese workforce and those in need of public support. Also between 2008 and 2012, the proportion of children up to age 17 living in jobless households nearly doubled in Portugal and Spain (UNICEF 2014).

Throughout the country many social canteens were created within the context of the government programme of "food emergency". In the first semester of 2015 around 8.6 million of meals were served. In partnerships with Mayors, local authorities and parents' associations, schools have also reinforced the social support to children and their families, by keeping open the school canteens during Summer holidays to provide children with "the only full hot meal".

Portugal has one of the most unequal income distributions in Europe and poverty levels are high (OECD 2014b). The economic crisis has halted a long-term gradual decline in both inequality and poverty and the number of poor households is rising, with children and youngsters being particularly affected. Uunemployment was also a factor impacting on the risk of poverty and on social exclusion, $40.5 \%$ and $25.7 \%$ respectively. The tendency for risk of child poverty was higher than for the rest of the population and this trend was similar to the figures in the European Union (UE27).

Also, the effects of the financial and economic crisis on education were clearly visible (INE-Portugal 2015). Children were the population group that has been at higher risk of poverty and social exclusion than any other group (since 2010) and they have been the most affected by the increase of poverty and social exclusion (more 3.8 p.p. between 2012 and 2013). The risk of poverty for children is in inverse proportion to the level of schooling of their parents, being $37.5 \%$ for those whose parents have not completed at least secondary education; $14.1 \%$ for those whose parents concluded secondary or postsecondary education (non-higher education) and $4.1 \%$ for those whose parents held higher qualifications.

Despite the important progress made by Portugal over the last three decades after the entry to the then European Economic Community, existing data related to Education are still below the average of the UE28. For example, the population between 25 and 64

\footnotetext{
${ }^{1}$ Fonte: http://www.jn.pt/Paginalnicial/Nacional/Interior.aspx?content_id=4731106
} 
years of age who had completed at least the secondary education is $40 \%$ in Portugal against $75.2 \%$ in UE28; also, the school dropout rate between 18 and 24 years old is $19.2 \%$ and $11.9 \%$, respectively (PORDATA 2014). In Portugal, the "New Opportunities" programme was launched in 2005 to provide individuals who left school with a second opportunity to do their studies, and to assist those in the labour force who want to acquire further qualifications. As a result of this initiative, graduation rates rose by more than $40 \%$ between 2008 and 2010. In 2010, more than $40 \%$ of the students concerned were older than 25 (OECD 2014b). In 2011, however, the Ministry of Education has initiated a process of closing down this programme. Issues related to some of the procedures used in the process of certifying people's competencies, amongst other features, were key reasons for abolishing the programme.

Nowadays school and teachers' lives are marked greatly not only by the need to educate children but also by social issues, especially by the alarming dimension of poverty. Therefore, schools and teachers are facing challenging circumstances in their own work and lives in relation to greater social intervention demands.

\section{The Education sector in a context of crisis}

According a recent report titled "The State of Education in a State under an intervention programme" (Benavente et al 2014), the budget for Education has increased from 1.4\% of the GDP in 1972 to $4.6 \%$ in 1995 until it reached 5.7\% in 1998. Currently, it is around $3.8 \%$, one of the lowest in the UE. This report characterises the changes in the Education sector after 2011 as follows: i) increase of the number of pupils per class; ii) return to the selection of pupils through the introduction of national exams at all levels of schooling in order to guide some of them to vocational programmes; iii) increase in teachers' workload; iv) reduction in staffing levels, especially with the school curriculum restructuring leading to the disappearance of given curriculum areas - such as project area - and school support for pupils. This situation had led to an increase of $151 \%$ of teachers' unemployment (taking into account the figures in 2011); v) creation of the mega-clusters of schools (a number of schools that merge in a given municipality and are run by one principal, not one principal per school anymore); vi) promotion of the school rankings based on national exams; vii) reinforcement of the so-called key subject matters, such as Portuguese and Maths; viii) abolition of transversal and cross-curricular areas such as 
Study under Guidance and Project Area; ix) reduction in attention to subject matters such as Physical Education, Artistic education, Civic Education and Health Education.

The teaching workforce has lost more than 30,000 jobs $^{2}$, and is now the profession with the highest level of unemployment, with $26.4 \%$ of teachers registered at the governmental Institute for Employment and Professional Training (Instituto de Emprego e Formação Profissional - IEFP) ${ }^{3}$. In 2011, there was an increase in $120 \%$ in relation to the unemployment rate of 2009, and in 2012 the increase was $225 \%$. Teachers' salaries have also been reduced along with an increase in their workload and the worsening of their working conditions (see Flores, Ferreira and Parente 2014). Research has demonstrated the intensification, the increase in bureaucracy, and low morale of teaching workforce (Flores, 2014). In a recent nationwide survey $(n=2702)$, the majority of teachers $(61.6 \%)$ admitted that their motivation decreased in the three years since 2012 (Flores, Viana \& Ferreira, 2014). They claimed that teachers' workload has increased over the past three years (96.7\%), that there was a greater control over their work $(75.6 \%)$, and that there was an increase of teachers' public accountability (74.6\%), and an accentuation of criticisms of teachers $(92.2 \%)$. They blamed, to a great extent, the role of the media in the deterioration of the public image of teaching and teachers.

At the same time more pressure has been put on schools and teachers to increase student attainment, as a result of concerns with national and international assessment programmes. Issues of accountability and performativity have been identified in some of the policy initiatives, especially those related to school internal and external evaluation, teacher evaluation and pupil assessment, with particular emphasis on national exams for new entrants into the teaching profession, and for pupils in year 4, year 6 and year 9 in Portuguese and Maths.

Alongside these, a number of policy initiatives have been introduced in order to deal with the complex demands of school life as a result of the financial, economic and social crisis. Amongst others, since 2012, emergency and compensatory policies, programmes and measures have been put into place by the Ministry of Education, such as: i) the definition of "learning goals" in pre-school; ii) the development of the third generation of TEIP (the so-called Educational Territory of Priority Intervention - TEIP 3 ), in order to deal with policies for priority education in socially and economically

\footnotetext{
${ }^{2}$ Source: http://www.dn.pt/inicio/portugal/interior.aspx?content_id=3417596

${ }^{3}$ Based on IEFP official data, in August 2012 (in the subsequent years IEFP did not disclose data): http://www.dn.pt/inicio/portugal/interior.aspx?content_id=2772404\&page=-1
} 
deprived areas with dropout rates higher than the national average (in total, $16 \%$ of the Portuguese schools benefit from this government programme); iii) the "Alternative Curriculum Paths" aimed at pupils in elementary education with learning difficulties, recurrent academic failure, risk of social exclusion and/or school dropout; iv) the "Integrated Programme for Education and Training" as a socio-educational policy initiative aimed at inclusion, in a transitional way, of youngsters at age 15 to 18 that were at risk of social and/or school exclusion; v) the school programme for "Food Reinforcement" (PERA 2012) aiming at providing pupils in need with a meal in the morning (around 14,000 and 12,000 pupils benefited from this programme in 2012/2013 and 2013/2014, respectively); and vi) The "Education and Training Programmes" aimed at youngsters (15-25 years of age) and adults (18 years or beyond), in order to deal with school dropout and school failure, to support pupils at risk of leaving school, to reintegrate those who had given up school and to consolidate the school training with double certificates: vocational and academic at the level of secondary education.

Within the context of such policy changes and such complex social and economic context, it is important to analyse the ways in which teacher education is responding to these challenges, particularly in regard to the context of practicum taking into consideration student teachers' perspectives.

\section{Initial Teacher Education (ITE) in the post-Bologna context in Portugal}

Like other European countries, Portugal has undergone a restructuring process of ITE programmes as a result of the implementation of the Bologna process. According to the legal framework (Decree-Law $n^{\circ}$ 43/2007), the professional qualifications for teaching (from pre-school to secondary education) are to be based on a number of key elements: i) a higher professional qualification for teachers (at a second cycle level, i.e., master's degree); ii) a curriculum based upon leaning outcomes in the light of teacher performance; iii) a research-based qualification; iv) the importance of practicum (observation and collaboration in teaching situations under the supervision of a mentor/supervisor); v) school-university partnerships; and vi) the quality assurance of teachers' qualification and of initial teacher education (ME, 2007). Thus, in order to become a teacher, a three-year degree (licenciatura) is needed, plus a master's degree in teaching (usually a two-year programme). It implies, therefore, the separation between training in the first cycle (threeyear programme called licenciatura) and training at second cycle level (master's degree 
which is now required to enter the teaching profession from pre-school to secondary education). In 2014 a new legal framework for ITE in Portugal was published (DecreeLaw $n^{\circ}$ 79/2014) which includes the following curriculum components: i) training in the

subject matter; ii) general educational training; iii) specific didactics (for a given level of teaching and subject matter); iv) cultural, social and ethical education, and v) professional practice. However, the cultural, social and ethical education component receives no specific credits.

The new configuration - within the context of a consecutive model - has been seen as a drawback in relation to previous models of teacher education (i.e. the so-called integrated model which included four to five years of training in which student teachers would benefit from training in educational sciences and subject matter simultaneously from the very beginning of the course, plus one year of practicum in a school). The new model, based upon a more fragmented curriculum through different courses in every semester - some of them subdivided in modules, often as a result of academic disputes over disciplinary territories - emphasises subject knowledge and didactics which implies that the professional practice occurs more at universities with less time spent in schools. (e.g. Flores 2011; 2014b; Flores, in press, Flores et al, in press). This trend towards academisation is evident elsewhere in Europe as ITE shifts focus from practical skills towards academic meritocracy (Ek, Ideland, Jönsson and Malmberg 2013). However, in other European countries and elsewhere ITE has followed the opposite trend (see, for instance, the UK and the USA).

By and large, recent policy changes have impacted upon initial teacher education, in terms of curriculum and knowledge fragmentation, and an emphasis on the didactics component, making it difficult to focus on the wider social and cultural problems in which teachers work. It is also important to note that in Portugal teacher surplus and unemployment became two intertwined realities, with implications for the recruitment of student teachers in higher education institutions and for new teachers' job expectations.

\section{Methods}

This paper reports on data drawn from ongoing research on the effects of child poverty on teaching and teacher education in a context of social and economic crisis. It addresses the following research questions: How do student teachers look at poverty during practicum and its effects on pupils and schools? What kinds of poverty situations do they 
describe? What do they learn from their practicum experience, particularly in regard to strategies to deal with poverty? How does initial teacher education address poverty?

Student teachers enrolled in ITE programmes for pre-school and primary schools were invited to participate in the project. Out of the 24 and 28 student teachers who enrolled in the Master's degree in Pre-school and in both Pre-school and Primary school, respectively, 19 of them volunteered for this study. All of them were female and their ages ranged from 21 to 24 years. Eleven were doing a Master's Degree in Pre-school and seven a Master's degree in both Pre-school and Primary school. In Portugal, ITE for preschool and primary schools is at Masters level ( $2^{\text {nd }}$ cycle) following the 3-year degree (Licenciatura) in Basic Education (1st cycle).

None of the researchers taught in these programmes and one of them has asked for permission from the directors of the Master's degree programmes to invite the students to participate in the study and to obtain informed consent. Data were collected during a Seminar at the university which took place in May 2015.

Student teachers were asked to do their written narratives (about two-pages length) in the light of a number of questions aiming at exploring their beliefs, conceptions and experiences of poverty during their practicum: Initiation to professional practice $\left(1^{\text {st }}\right.$ degree) and Supervised Teaching Practice (Master degree level). During practicum student teachers have the opportunity to observe and to teach a number of lessons under the supervision of a cooperating teacher and a university supervisor. Written narratives are powerful in providing participants with the opportunity to reflect on their learning experiences as well as to raise awareness and promote reflection on beliefs and implicit theories and making sense of their own experience (Elliott 2005). Through these narrative accounts the participants were invited to look back on specific moments or situations and learning from them through a process of meaning making (Hollway and Jefferson 2000; Elliott 2005), which is particularly relevant within the context of teacher education, and in this case after practicum. Issues of time and space and the social context (Clandinin, Pushor and Orr 2007) are in this regard of paramount importance.

Data analysis was undertaken according to two phases: a vertical analysis (Miles and Huberman 1994) according to which each of the respondents' accounts was analysed separately. The second phase included a comparative or horizontal analysis (cross-case analysis) (Miles and Huberman 1994) during which the method of 'constant comparative analysis' (Glaser and Strauss 1967) was used to look for common similarities as well as differences. Coding was carried our according to semantic criteria and emerging 
categories were identified from the accounts and were validated by both researchers.

\section{Findings}

In this section findings arising from student teachers' accounts are presented, according to the main emerging themes: i) student teachers' perceptions of poverty and its impact on children's well-being; ii) strategies to deal with poverty at school; iii) teachers' complex role in a context of crisis: promoting equity and social justice; iv) ITE and the need to pay attention to the social and cultural dimension of teaching.

\section{Student teachers' perceptions of poverty and its impact on children's well-being}

In their accounts student teachers spoke of the ways in which they perceived poverty during their practicum in Kindergarten and pre-schools. Most of them talked about situations of poverty which they observed during practicum. They illustrated their perceptions describing concrete situations that have had an impact upon them and they also identified the effects of the economic crisis upon children's life and well-being:

"Poverty in schools is actually a very critical issue that worries me because it influences the ways in which children learn and relate to other people".

"Poverty, in many cases, affects children at school. They lack motivation that may arise from their family context and it can lead to pupils' lack of interest in regard to school".

"You can see the effects of poverty at school and even at the school atmosphere. Children feel the effects of poverty and they actually talk about that when they are in the playground. This is visible in the ways in which they play and they actually integrate this reality in their role-playings".

However, some of the participants state that they have not observed any situation related to poverty: 
"During my practicum I have never come across children with economic difficulties."

"I have never seen any situation which you could relate to poverty".

However, the majority of the students did claim that it was possible to identify poverty situations during their practicum and they highlighted their real effects on children. In their accounts there are abundant examples of the effects of the economic and social crisis at various levels: lack of school material, early dropouts, children clothing, lack of food, etc.

"During my practicum I saw a child with Special Needs who was going to Kindergarten without having had breakfast because her parents had economic difficulties."

"Many children go to school without having had breakfast and this of course affects their learning."

"I was able to see that some children went to school without having had breakfast at all!" The economic difficulties experienced by families have been exacerbated in Portugal over the last few years with the crisis and the austerity measures imposed by the government as a result of the external intervention of the Troika. Higher taxation, salary cuts, a decrease in financial support for families and the high level of unemployment have led to critical situations especially when both parents became unemployed. As a consequence of the economic crisis, schools had to be open during Summer holidays in order to provide meals for pupils. Student teachers report situations that are eloquent of the effects of the crisis on children's life and on their behaviour at school: inadequate clothes, lack of resources, famine, etc. Some of these situations were not familiar to the student teachers who express surprise in relation to what they have observed at school.

"I did see a child who used to wear the same clothes every single day and the clothes were not adequate to his size. This child had shower at the school!"

"When you ask to children to bring material to school or money for a school visit, some children are not able to do it at all!" 
The participants' accounts also point to the difficulties in doing their job during practicum not only due to the lack of material and resources but also as a result of children's behaviour and lack of motivation:

"When the school doesn't have the required resources for children to learn, as a teacher you cannot provide them with learning experiences that may challenge them. It becomes difficult to get children motivated to learn if you don't have the materials that you need." "The classroom conditions and facilities don't promote success; if there are no materials in the classroom, as a teacher your work is going to be undermined."

"If the school doesn't have the materials for children to play and learn, of course this will affect negatively their success and their learning."

Student teachers reveal that the lack of resources at school and the lack of funding lead them to change their pedagogical activities with implications for children's learning and development:

"For instance, the lack of material makes you change or postpone some activities. Actually it happened to me. Because of the lack of material, I had to postpone one of the activities during my practicum and it would be really interesting for children."

"The lack of material makes your job as a teacher much more difficult. Also, the increasing poverty can be seen in pupils' failure and in their misbehaviour in regard to their colleagues and teachers".

But it is not only on pupils' learning and on teachers' work that the students' accounts focused as a consequence of poverty. The participants also spoke of children's leisure time and the fact that some of them cannot attend some of the activities:

"In the Kindergarten where I did my practicum one child was not able to go to the beach because his parents didn't have money to pay for it."

"Not all of the pupils go to beach for instance because their parents cannot afford it". "I remember that one child has given up from the Kindergarten because of economic problems and she went to her grandmother's house." 
As this last quote illustrates, one of the consequences of the crisis and accentuation of economic difficulties is the early dropout of children from school.

"If children are not motivated due to lack of resources and support they give up after compulsory education".

"Being at school is expensive and nowadays parents need to pay much more for school materials and textbooks which lead to dropout because they cannot afford it".

As previous literature has demonstrated, poverty directly affects academic achievement due to the lack of resources available for student success. In other words, low achievement is closely correlated with lack of resources. Empirical work has shown the correlation between low socioeconomic status and low achievement (Lacour and Tissington 2011).

\section{Strategies to deal with poverty at school}

Student teachers were asked about the ways in which teachers and schools and also themselves as trainees deal with poverty and its effects on school. They were asked to describe concrete situations that they have experienced. Most of them highlighted the role of teachers in helping the children with economic difficulties, by providing them with personal and financial support and by creating alternative approaches to responding to shortages of resources.

"From what I have heard, for teachers and early childhood carers this situation is very difficult to deal with. They try to come up with alternative solutions in order for the children dropout doesn't happen. Many of them do even pay for the food for children."

"Many times I saw teachers bringing materials from them homes and spending their money in buying stuff for children.”

"The teacher tries to minimise the situation by giving children food and clothes."

"During my practicum I saw that teachers were concerned about situations of poverty and they were offering different sorts of food and trying to find funding to take as many children as possible to the beach during holidays". 
“Teachers try to handle poverty situations by bringing materials and food to school."

"The school where I did my practicum tried to help children with economic difficulties, for instance, for one child with special needs two people with training in special education were hired to help him."

Issues of social support and help to children - the most vulnerable element in the national picture - and their families need to be taken into account in order to develop strategies to avoid school dropout and absenteeism and to promote student achievement.

Other participants - a minority - refer to some teachers' lack of special attention to poverty issues at school:

"In general, I think that schools, especially teachers, think that poverty issues have nothing to do with them... even if it affects children's learning".

\section{Teachers' complex role in a context of crisis: promoting equity and social justice}

Most of the participants talked about their professional learning during their practicum and the ways in which they have become more aware of their pivotal role in promoting equity and social justice through facilitating and acting as facilitators of access to powerful knowledge for all children. Issues of increasing awareness of poverty issues and children's needs, managing scarce resources, advocating in practice for equity and social justice were at the forefront of their accounts:

"As a professional-to-be I am now more aware of what I am going to find out at school and how to deal with it."

"I have learned that you need to do whatever you can with only a little."

"The adaptation to difficult socio-economic contexts makes you reutilise things and materials in order to avoid spending money both in your home and in your workplace."

"As a teacher-to-be these kinds of experiences contributed to adjust my practice in order to provide equal opportunities for pupils to learn." 
"My practicum gave me the opportunity to get to know these kinds of situations and learn some strategies that I may use to minimise them."

"It made me realise that being a teacher is also about being able to help children not only in their learning but also economically."

"I was given the opportunity to learn some techniques and activities. Project work with the kids was new to me and I have learned a lot."

"To me practicum was very important because it made me reflect upon the current situation especially about the crisis and how it can affect a child's life. It made me think about possible solutions to deal with these situations."

"It made me realised that as a professional-to-be I need to pay attention to children's needs and help them because they are entitled to education".

One of the issues that deserves further attention in this regard is the need to update the foundational democratic project of the school in so far as the principle of "equal opportunities" has been called into question due to recession and to the economic and social crisis. Schools and teachers, and also institutions for ITE, have to ask the question identified by Young (2011) "what are schools for?". What is at stake is the democratisation of schooling but also the democratisation of culture, because social and cultural goods are those that are most affected by austerity. People finding themselves in a critical economic situation start to cut down in these kinds of goods. Teachers as agents of change and workers of knowledge have a key role in promoting the social and cultural dimension of children and their families. And ITE needs to prepare them for that.

\section{ITE and the need to pay attention to the social and cultural dimension of teaching}

Looking back on their initial teacher education programme, some participants state that poverty issues were discussed in two modules but the vast majority said nothing about the theme or stated that these issues were not taken into consideration while at university: "I haven't discussed these kinds of issues", "It was not discussed during my ITE 
programme". Others state that they cannot remember: "I don't remember, unfortunately, but the discussion of these kinds of issues was minimal". Others do state that they had discussed poverty and its implications during their ITE programme:

"I did discuss these issues in the modules of Sociology of Childhood and Education during my first degree in my second year at university. We did work on that and we read texts about that too."

"This issue was dealt with in the module of Multicultural Education in my Master's degree. It was very superficial though..."

"Poverty is a critical issue especially because of the economic situation in our country. Poverty is much more visible those days..."

"I think it is important to look at these kinds of issues in ITE curriculum, because as a teacher you can see it more and more in kindergarten and pre-school."

Most of the participants identified suggestions and recommendations for initial teacher education in order to include issues related to poverty, social justice and equity in its curriculum:

"Unfortunately, it [poverty] is a theme that is really visible in Portuguese schools. And I think it is necessary to look at how to deal with this situation during your training at university."

"It would be useful to include issues of poverty in ITE curriculum as it is more and more present in schools. It would be important to examine how to deal with these situations and, who knows, to actually go to places where poverty is more visible and to see how it is dealt with in practice".

"It is really essential to discuss poverty in ITE curriculum because it is more and more present at school in our country. Teachers need to undertake professional development courses in order to develop their competencies to deal with it." 
"I think it is important that student teachers at Basic Education are provided with information and strategies that enable them to deal with different contexts, as in the future you may end up teaching in one school where you may find poverty situations."

"My opinion is that there should be a curricular unit at university that helps you in analysing real problems that you face during practicum."

"If these kinds of issues were to be examined at ITE, they should be practical by inquiring and looking for solutions in real contexts."

One of the possibilities might be the inclusion in the ITE curriculum of issues related to Children's rights, which are far from being a reality, more than two decades years of the publication of the Convention on the Rights of the Child (1989). Existing literature suggests that teachers' and headteachers' perceptions and attitudes to social class and poverty in the classroom point to the lack a critical perspective on context and fall back on deficit models from a middle class perspective of the norm (see, for instance, Gorski 2012; Lupton and Thrupp 2013).

\section{Discussion and implications for teacher education}

"The child should be fully prepared to live an individual life in society, and brought up in the spirit of the ideals proclaimed in the Charter of the United Nations, and in particular in the spirit of peace, dignity, tolerance, freedom, equality and solidarity." (Convention on the Rights of the Child 1989).

This paper set out to reflect upon issues of child poverty in the Portuguese context after the financial, economic and social crisis over the last few years. Its aim was twofold: i) to look at the macro level by examining recent policy documents and other reports on the Education sector and ii) to analyse the ways in which initial teacher education deals with poverty issues, within the post-Bologna context, through the voices of student teachers after having finished their practicum at school. Despite the limitations of the study in terms of participants (all volunteers), findings raise issues related to equity and social justice and highlights the need for teachers to be aware of the social and cultural dimension of their complex and demanding role, particularly in times of crisis. 
From the data, three main ideas may be identified. First, the relevant documents about education as well as existing research pointed to the deterioration of working conditions at school for teachers and, as a result of the economic and social crisis, greater challenges and pressures were put into them. Student teachers participating in this study also reported evidence of the more and more complex demands placed upon schools and teachers who, apart from teaching, have to deal with social issues such as child poverty, lack of motivation, scarcity of resources, etc. Their accounts are illustrative of the difficulties that most teachers have to go through in their work especially in regard to families in a critical economic situation. Issues of diversity, equity and social justice were also discussed in their accounts. Student teachers' accounts reveal their perceptions about poverty and its impact on children's well-being and equal opportunities.

Secondly, the strategies used by teachers to face poverty situations have made student teachers more aware of their lack of preparedness to deal with teaching in such a demanding context. Being and feeling like a teacher in a real context is seen as an opportunity for student teachers not only to realise the demanding nature of their work but also its complexity and social dimension. Examples of strategies employed by the teachers included providing individual personal and financial support and creating alternative approach to responding to shortages of resources, etc. Findings stress the complex and pivotal role in promoting equity and social justice through facilitating and acting as a facilitator of access to powerful knowledge for all children. As Young (2011) suggests, there is a need to move beyond the "knowledge of the powerful" and to take into account the "powerful knowledge". In discussions about the school curriculum, it is important to know if the knowledge available at school is powerful, which means, knowledge that enables pupils to understand the world in which they live: "There is a link between the emancipatory hopes associated with the expansion of schooling and the opportunity that schools provide for learners to acquire «powerful knowledge» that they rarely have access to at home" (Young, 2011, 155).

Finally, findings also point to the need to reinforce the social and cultural dimension of initial teacher education. Although it is seen as a key component for ITE curriculum in the Portuguese legal text, it is up to the higher education institutions to make decisions on how to implement it as there are no compulsory credits allocated to it. The aim is to include the ethical, social and cultural dimension within the other components which have a required number of credits attached to them. ITE plays a key role in demanding times in Portugal not only in providing student teachers with a more 
complex and broad picture of the teaching profession but also in terms of a wider and critical debate about education, especially concerning policy, school organisation, curriculum and pedagogy. Talking about the USA context, Zeichner (2010) discusses the commodification of teacher education, its hyperrationality and increased accountability, and attacks on multicultural education. Also Sleeter (2008) analyses the ways in which equity and democracy have been undermined and she identifies three neoliberal pressures on teacher education: away from explicit equity-oriented teacher preparation, and toward preparing teachers as technicians; away from defining teacher quality in terms of professional knowledge, and toward defining it terms testable content knowledge; and toward shortening university-based teacher education or by-passing it altogether. Other existing empirical work suggests that pre-service teachers' attitudes to poverty are often also deeply ingrained and resistant to change (Cox, Watts and Horton 2012).

The participants in this study were clear about the role of ITE. They clearly highlight some areas which ITE needs further improvement. Most of them relate to social and cultural issues. Recent trends in ITE in Portugal tend to emphasise the technical and didactical side in detriment to other key dimensions (see Flores, in press).

Teachers are agents of change and workers of knowledge and thus they have a pivotal role in promoting the social and cultural dimension of children and their families. ITE needs to prepare them for that. In times of high unemployment rate ITE may need to be re-examined and re-invented in order to meet the challenges of a global society and the needs of the schools of the $21^{\text {st }}$ century. One way of moving forward is to develop a broader understanding of ITE associated with social and cultural issues, teachers as agents of change and workers of knowledge and schools as places where culture, leisure and other aspects need to be considered in different ways.

The economic crisis and austerity measures have affected profoundly school and teachers' lives along with changes in policy and curriculum of ITE in the post-Bologna context, namely towards an accentuation of the academic and didactical perspective to the detriment of a more humanistic and critical approach open to discuss social issues with pupils, families and local communities.

This is in line with other literature which points to the need to reinforce the ethical, cultural, social and political dimension of teaching and teacher education (Tirri, 2014; Zeichner 2014; Flores, in press). Tirri $(2014,15)$, for instance, in Finland identified the need for a set of competencies for "professional and ethical" teachers in the light of the 
moral dimension of their work in dealing with a rising number of immigrant students and children with difficulties. Similarly, in the USA, Zeichner $(2014,560)$ argued that "the teacher as a professional view goes beyond providing teachers with teaching and management skills". More needs to be done in this regard also in the Portuguese context. Children growing up in poverty and disadvantage contexts are less likely to do well at school, which, in turn, has implications for their later life and it may affect their children too. To move beyond this cycle, ITE can play a pivotal role in addressing the attitudes and experiences that lie behind social differences in education. The project upon which this paper is based aims to make a contribution to the discussion and consideration of the ethical, social and cultural dimension in ITE programmes. Another implication lies in pupil voice. In such demanding times it is more important than ever to pay attention to pupils' voices and the ways in which the school and the curriculum affects their lives, their learning and their motivation through their own views and experiences.

\section{References}

Benavente et al 2014. O estado da educação num estado intervencionado. Portugal 2014. lisboa: op.edu - observatório de políticas de educação e de formação. Ces . Uc . Ceied.Ulht

Clandinin, D. J.; Pushor, D. and Orr, A. M. 2007. Navigating sites for narrative inquiry, Journal of Teacher Education, 58(1), pp. 21-35

Convention on the Rights of the Child, 1989

Cox, B. J. , Watts, C. and Horton, M. 2012. Poverty Perceptions of Pre-Service teachers and Social Work Candidates. Journal of Studies in Education, 2(1), 131-148.

Ek, A.-C.; Ideland, M.; Jönsson, S. \& Malmberg, C. 2013. The tension between marketisation and academisation in higher education, Studies in Higher Education, 38:9, 1305-1318

Elliott, J. 2005. Using Narrative in Social Research. Qualitative and Quantitative Approaches,Londres: Sage.

EU 2013. Social Europe. Many ways, one objective. Annual Report of the Social Protection Committee on the social situation in the European Union.

Flores, M. A, Ferreira, F. I. and Parente, C. 2014. Conclusões e recomendações, in M. A. Flores (Coord.) Profissionalismo e liderança dos professores, (pp.217-236), Santo Tirso: De Facto Editores

Flores, M. A. 2011. Curriculum of initial teacher education in Portugal: new contexts, old problems. Journal of Education for Teaching, 37(4), 461-70.

Flores, M. A. 2014. (Ed.) Profissionalismo e liderança dos professores. Santo Tirso: De Facto Editores.

Flores, M. A. (2014b). Teacher learning in the workplace in Pre-service Teacher Education in Portugal: Potential and limits from a Pre-service teacher perspective. In O. McNamara, J. Murray, \& M. Jones (Eds.), Workplace Learning in Teacher Education. International Practice and Policy (pp. 243-260). Dordrecht: Springer. 
Flores, M. A. (forthcoming) Teacher Education Curriculum, in. J. Loughran \& M. L. Hamilton (Eds.) International Handbook of Teacher Education, Dordrecht: Springer Press.

Flores, M. A., Veira, F., Silva, J. L., \& Almeida, J. (forthcoming). Integrating research into the practicum: making the best of difficult circumstances in post-Bologna initial teacher education in Portugal, in M. A. Flores \& T. Al Barwani (Eds.) Redefining teacher education for the Post-2015 Era: Global challenges and best practices. New York: Nova Publishers.

Glaser, B. G. \& Strauss, A. L. 1967. The Discovery of Grounded Theory: Strategies for Qualitative Research. Chicago: Aldine.

Gorski, P.C. 2012. Perceiving the Problem of Poverty and Schooling: Deconstructing the Class Stereotypes that Mis-Shape Education practice and Policy. Equity and Excellence in Education, 45(2), 302-319.

Hollway, W. and Jefferson, T. 2000.. Doing qualitative research differently. Free association, narrative and the interview method. London: Sage.

INE-Portugal 2015. Inquérito às Condições de Vida e Rendimento 2014 (dados provisórios). Lisboa: INE.

Lacour, M. and Tissington, L. 2011 The effects of poverty on academic achievement, Educational Research and Reviews. 6 (7), 522-527

Lupton and Thrupp 2013. Headteachers' Readings of and Responses to Disadvantaged Contexts: evidence from English primary schools. British Educational Research Journal, 39(4), 769-788.

Miles, M. \& Huberman, M. 1994. Qualitative data analysis. An expanded sourcebook

(2nd edition). Thousand Oaks: CA, Sage.

OECD 2014a.. Society at a Glance 2014 OECD Social Indicators

OECD 2014b.. OECD Economic Surveys: Portugal. OECD Publishing

OECD 2015. Education at a Glance Interim Report: Update of Employment and Educational Attainment Indicators. Trends in educational attainment: 2000-2013

OECD 2015, International Migration Outlook 2015, OECD Publishing, Paris.

OMEP 2010.. Children's Voices about the State of the Earth and Sustainable Development. A report for the OMEP World Assembly and World Congress on the OMEP World Project on Education for Sustainable Development 2009-2010.

OXFAM 2013. The true cost of austerity and inequality. Portugal Case Study. https://www.oxfam.org/sites/www.oxfam.org/files/cs-true-cost-austerityinequality-portugal-120913-en.pdf

Pires, R.P., Pereira, C; Azevedo, J and Ribeiro, A. C. 2014, Emigração Portuguesa. Relatório Estatístico 2014, Lisboa, Observatório da Emigração e Rede Migra, Instituto Universitário de Lisboa (ISCTE-IUL), CIES-IUL, e DGACCP.

PORDATA 2014. Retrato de Portugal na Europa. Edição 2014. Lisboa: Fundação Francisco Manuel dos Santos

Sleeter, C. 2008. Equity, democracy, and neoliberal assaults on teacher education. Teaching and Teacher Education, 24, 1947-1957

Tirri, K. 2014. The last 40 years in Finnish teacher education. Journal of Education for Teaching, 40(5), 600-609.

UNDP 2013. United Nations Development Programme Poverty Reduction. Humanity Divided: Confronting Inequality in Developing Countries. Humanity Divided: Confronting Inequality in Developing Countries Empowered lives. Resilient nations. New York: United Nations Development Programme.

UNICEF 2013. As crianças e a crise em Portugal - Vozes de crianças, políticas públicas e indicadores sociais, 2013. 
UNICEF 2014. Children of the Recession The impact of the economic crisis on child well-being in rich countries. Florença: UNICEF Office of Research - Innocenti.

Young, M. 2011. What are schools for? Educação, Sociedade \& Culturas, nº 32, 2011, 145-155.

Zeichner, K. 2010. Competition, economic rationalization, increased surveillance, and attacks on diversity: Neo-liberalism and the transformation of teacher education in the U.S. Teaching and Teacher Education, 26, 1544-1542.

Zeichner, K. 2014. The struggle for the soul of teaching and teacher education in the USA. Journal of Education for Teaching, 40(5), 551-568. 